\title{
Tools for managing childcare in the postoperative period of cardiac surgery: an integrative review
}

\author{
Ferramentas para o gerenciamento do cuidado à criança no pós-operatório de cirurgia cardíaca: revisão integrativa
}

Herramientas para la gestión del cuidado infantil en el postoperatorio de cirugía cardíaca: una revisión integradora

Aline Cerqueira Santos Santana da Silva'

ORCID: 0000-0002-8119-3945

Marluci Andrade Conceição Stipp"

ORCID: 0000-0002-9534-6324

Graciele Oroski Paes "

ORCID:0000-0001-8814-5770

Virgínia Maria de Azevedo Oliveira Knupp' ORCID:0000-0001-5512-2863

Fernanda Garcia Bezerra Góes' ORCID: 0000-0003-3894-3998

José Antônio de Sá Neto"I ORCID:0000-0003-2296-2465

'Universidade Federal Fluminense. Rio das Ostras, Rio de Janeiro, Brazil.

"Universidade Federal do Rio de Janeiro. Rio de Janeiro, Rio de Janeiro, Brazil.

II'Universidade do Estado do Rio de Janeiro. Rio de Janeiro, Rio de Janeiro, Brazil.

How to cite this article:

Silva ACSS, Stipp MAC, Paes GO, Knupp VMAO, Góes FGB,

Sá Neto JA. Tools for managing childcare in the postoperative period of cardiac surgery: an integrative review. Rev Bras Enferm. 2021;74(Suppl 4):e20200073. doi: http://dx.doi.org/10.1590/0034-7167-2020-0073

Corresponding author:

Aline Cerqueira Santos Santana da Silva E-mail: alinecer2014@gmail.com

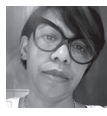

EDITOR IN CHIEF: Dulce Barbosa ASSOCIATE EDITOR: Priscilla Broca

Submission: 04-16-2020

Approval: 12-21-2020

\section{ABSTRACT}

Objective: To analyze the scientific literature on the application of management tools in the postoperative period of pediatric cardiac surgery. Methods: integrative review including studies published between 2004 and 2018 in the following databases: LILACS, BDENF, coleciona SUS, MEDLINE/PUBMED, CINAHL and SCOPUS, via Portal de Periódicos da Capes, Scientific Electronic Library Online (SciELO) and Academic Google research. Results: Twelve articles that met the inclusion criteria were analyzed. The studies demonstrated that strategies such as extracorporeal membrane oxygenation, renal replacement therapy and the risk scores for Risk Adjustment for Congenital Heart Surgery 1 and Aristotle Basic Score favored the stratification the demand for care and predicted the risk for mortality. Final considerations: The applicability of risk scores and emerging strategies for the management of childcare in the postoperative period of cardiac surgery was described by the evaluation of possibilities of performance and/or efficiency of the treatments developed.

Descriptors: Pediatric Nursing; Organization and Administration; Critical Care; Thoracic Surgery; Postoperative Period.

\section{RESUMO}

Objetivo: Analisar a literatura científica acerca da aplicabilidade de ferramentas gerenciais no pós-operatório de cirurgia cardíaca pediátrica. Métodos: Revisão integrativa, entre 2004 e 2018, nas bases de dados LILACS, BDENF, coleciona SUS, MEDLINE/PUBMED, CINAHL e SCOPUS, via Portal de Periódicos da Capes, no Portal de Revistas Scientific Electronic Library Online (SciELO) e busca no Google Acadêmico. Resultados: Foram analisados 12 artigos que atenderam aos critérios de inclusão. Os estudos demonstraram que estratégias, como o uso de oxigenação por membrana extracorpórea, a terapia de substituição renal e os escores de risco Risk Adjustment for Congenital Heart Surgery 1 e a Complexidade Aristotle Basic Score, favoreceram estratificar a demanda de cuidados e predizer o risco para mortalidade. Considerações finais: A aplicabilidade de escores de risco e estratégias emergentes para o gerenciamento do cuidado à criança no pós-operatório de cirurgia cardíaca configurara-se como possibilidade de avaliação de desempenho e/ou eficiência nos tratamentos instituídos. Descritores: Enfermagem Pediátrica; Gerência; Cuidados Intensivos; Cirurgia Cardíaca; Período Pós-Operatório.

\section{RESUMEN}

Objetivo: Analizar la literatura científica sobre la aplicabilidad de herramientas de gestión en el postoperatorio de cirugía cardíaca pediátrica. Métodos: Revisión integrativa en las bases de datos LILACS, BDENF, coleciona SUS, MEDLINE/PUBMED, CINAHL y SCOPUS en el Portal de Revistas Scientific Electronic Library Online Journals (SciELO) y búsquedas en el Google académico. Resultados: se analizaron 12 artículos. Los estudios han demostrado que estrategias, como el uso de oxigenación por membrana extracorpórea, la terapia de reemplazo renal y las puntuaciones de riesgo Risk Adjustment for Congenital Heart Surgery 1 y la Complejidad Aristotle Basic Score, favorecieron la estratificación de la demanda de atención y la predicción del riesgo de mortalidad. Consideraciones finales: La aplicabilidad de puntajes de riesgo y estrategias emergentes para la gestión del cuidado infantil en el postoperatorio de cirugía cardíaca se configuró como una posibilidad de evaluación del desempeño y/o eficiencia en los tratamientos instituidos.

Descriptores: Enfermería Pediátrica; Gestión; Cuidados Intensivos; Cirugía Cardíaca; Período Postoperatorio. 


\section{INTRODUCTION}

Among the anomalies with the highest child morbidity and mortality rates, Congenital Heart Defects (CHDs) stand out for having an incidence of $9 / 1000$ live births ${ }^{(1)}$. Despite advances in early diagnosis and treatment, CHDs still account for $3 \%$ of all child deaths and $46 \%$ of deaths from congenital malformations ${ }^{(2-3)}$.

The complexity of the symptoms and care required by children with CHDs vary according to the type of heart disease and the clinical and hemodynamic repercussions ${ }^{(4)}$.

The evaluation of clinical parameters has become important in recent years. One of these parameters is the operative mortality risk associated with surgical correction of CHDs, which has become a classic parameter for evaluating the care provided in major health centers ${ }^{(5)}$.

Unlike the pediatric population in general, the adult population has risk stratification models and quality indicators that are used as management tools and are well developed and described. The creation of risk assessment models for the pediatric population requires a standard nomenclature of birth defects and surgical procedures according to the diversity of diagnoses ${ }^{(5-6)}$.

The ongoing evolution of the contemporary world makes it urgent to update practices in health service and requires qualified professionals to provide safe care ${ }^{(7)}$. Thus, management tools are incorporated into pediatric care with the objective of stratifying care demands and predicting the risk of mortality in the postoperative period of CHDs.

In recent years, tools have been described as instruments that are applied in the scope of care and contribute to the improvement of health care quality, especially in activities related to the flow of care and monitoring and evaluation of therapeutic processes ${ }^{(8)}$, which justifies the review of this topic. Also, as this is a critical care area, the tool is understood as an instrument that is used in thoughtful and organized care management ${ }^{(9-10)}$.

\section{OBJECTIVE}

Analyze the scientific literature on the application of management tools in the postoperative period of pediatric cardiac surgery.

\section{METHOD}

\section{Ethical Aspects}

This is a review study. Therefore, it does not involve human beings and does not need approval from the Research Ethics Committee.

\section{Study Design}

This is an integrative literature review, with a systematically ordered elaboration that makes it possible to gather and synthesize the research results on a given topic, favoring the expansion of knowledge and its incorporation into clinical practice ${ }^{(11)}$.

\section{Methodological framework and stages}

The standard steps of the method were followed, namely: elaboration of the guiding question; search and selection of articles in the literature; insertion of the studies in a data collection instrument made by the authors; evaluation of studies; interpretation of results; and synthesis of knowledge $\mathrm{e}^{(11)}$.

The research question was elaborated based on the search strategy known by the acronym $\mathrm{PICO}^{(12)}$, in which: Population (P): children in the postoperative period of cardiac surgery; Interest (I): use of management tools; and, Context (Co): care management.

Thus, the following research question was formulated: what management tools have been addressed in scientific research as instruments to manage the care provided to children in the postoperative period of cardiac surgery?

The next stage was the search for articles in the following databases: Latin American \& Caribbean Health Sciences Literature (LILACS), Nursing Database (BDENF), Bibliographic Collection of the Unified Health System (ColecionaSUS), International Science and Health Literature (MEDLINE) through the Pubmed site of the National Library of Medicine (USA), Cumulative Index to Nursing and Alllied Health Literature (CINAHL) of the EBSCO Publisher and SCOPUS of the ELSEVIER Publisher via Capes Journals, in the Scientific Eletronic Library Online (SciELO).

The controlled terms were used in Portuguese, English and Spanish and were associated in pairs and in trios using the Boolean operators "AND" and "OR". Quotation marks ("') were used to restrict and establish the order of two-word form. And the Boolean operators were used for the relationships between terms: AND was used for the intersection between the terms and OR was used for grouping/ sum of synonyms. The search strategies are shown in Chart 1.

Chart 1 - Presentation of descriptors and their combinations in the search databases, 2019

\begin{tabular}{|c|c|}
\hline Database & Descriptors (combination) \\
\hline \begin{tabular}{|l|} 
Portal \\
Regional da \\
BVS (LILACS, \\
BDENF)
\end{tabular} & 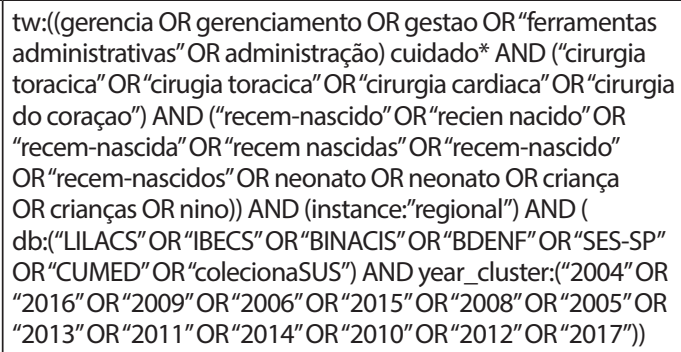 \\
\hline \begin{tabular}{|l|} 
Portal \\
Regional da \\
BVS (LILACS, \\
BDENF)
\end{tabular} & 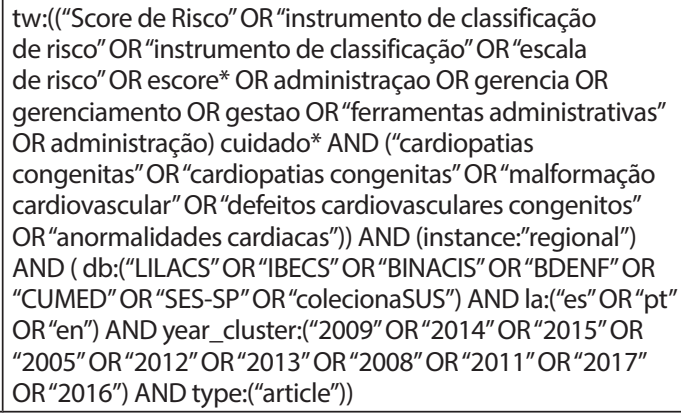 \\
\hline CINAHL & $\begin{array}{l}\text { ("Infant Newborn" OR "Infants, Newborn" OR "Newborn } \\
\text { Infant" OR "Newborn Infants" OR Newborns OR Newborn } \\
\text { OR Neonate OR Neonates OR Child OR Children OR } \\
\text { "Child Institutionalized" OR "Institutionalized Child" OR } \\
\text { "Children, Institutionalized" OR"Institutionalized Children" } \\
\text { OR Adolescents OR Adolescence OR Teens OR Teen } \\
\text { OR Teenagers OR Teenager OR Youth OR Youths ) AND } \\
\text { "Thoracic Surgery" AND Management }\end{array}$ \\
\hline
\end{tabular}


Chart 1 (concluded)

\begin{tabular}{|c|c|}
\hline Database & Descriptors (combination) \\
\hline PUBMED & 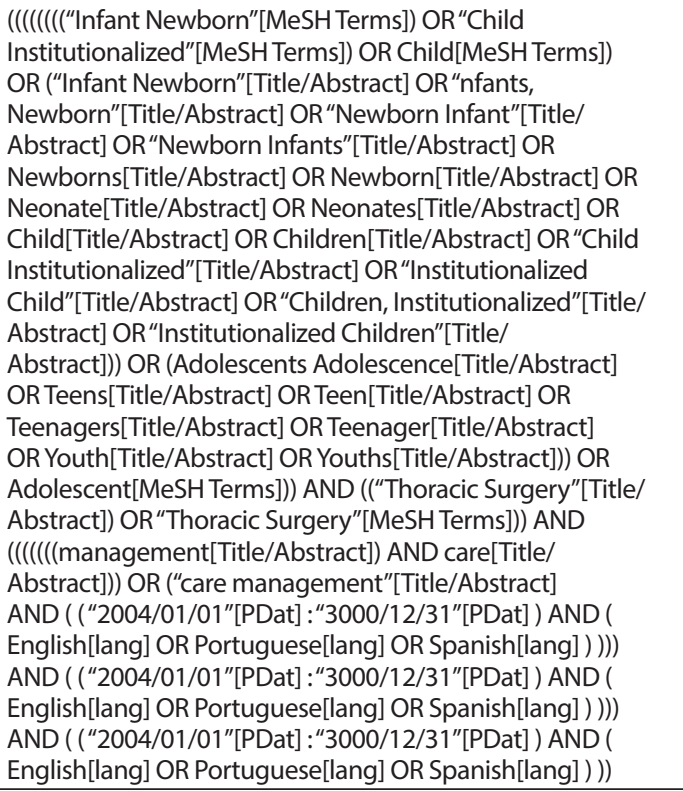 \\
\hline SCOPUS & 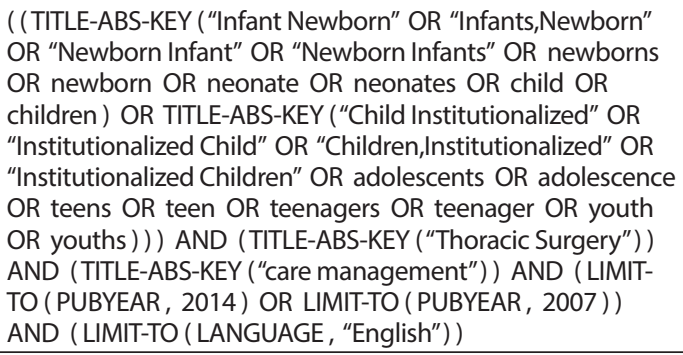 \\
\hline SCIELO & 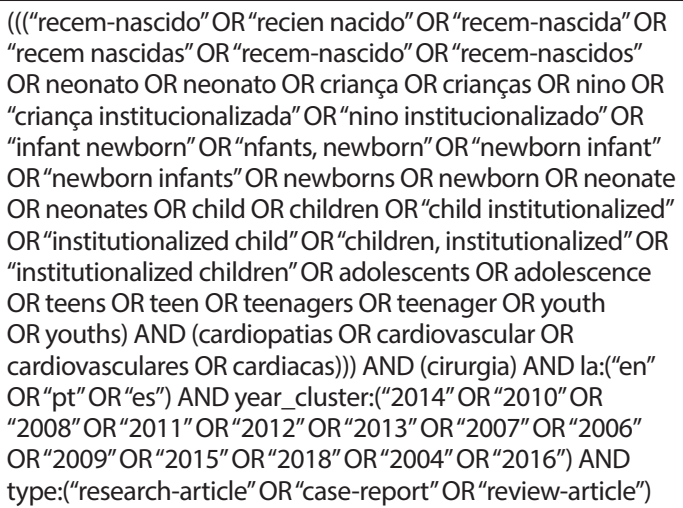 \\
\hline
\end{tabular}

The timeframe of 2004 to 2018 was established as it was necessary to increase the search period to collect more articles. The initial timeframe proposed was a 10-year interval (2004-2014). In 2018, the material was updated with the inclusion of newer evidence and the analysis was completed in 2019. The year 2004 is justified by the publication of Ordinance 1.169/GM, of June 15, 2004, which institutes the National Policy for High Complexity Cardiovascular Care, ensuring conditions for High Complexity Care Service in Pediatric Cardiovascular Surgery ${ }^{(13)}$. The eligibility criteria were: original studies available in full that met the research question. Studies developed with adults were excluded, as well as duplicate articles, letters, editorials, handbooks, and productions not related to the subject of the study. The studies selected were full articles published in Portuguese, Spanish and English, addressing the elements of the research question.
The search and selection of the studies included in the review were carried out by two independent reviewers, who read and evaluated the titles and abstracts of the selected articles according to the inclusion and exclusion criteria previously defined. Articles that addressed the referred topic were selected for reading in full. There were no disagreements between the reviewers on the inclusion of the manuscripts and both agreed on which studies had the necessary elements to answer the guiding question of this study.

An instrument developed by the authors was used to collect data from the articles, characterizing each study based on items such as the identification of the study, year, journal, location, objectives, characteristics about the method and theoretical framework, results and interventions. These data were organized and summarized in a database in Microsoft Excel 2007.

The level of evidence of the manuscripts was identified based on the study design according to the following criteria: I for systematic reviews or meta-analysis of randomized controlled trials; II for randomized clinical trials; III for controlled trials without randomization; IV for case-control or cohort studies; $V$ for systematic reviews of qualitative or descriptive studies; VI for qualitative or descriptive studies and VII for opinion of authorities and/or reports of expert committees. This hierarchy classifies levels I and II as strong, III to $\mathrm{V}$ as moderate and VI to VII as weak ${ }^{(14)}$.

\section{RESULTS}

The search resulted in the following distribution: $\operatorname{LILACS}(n=25)$; MEDLINE $(n=42)$; CINAHL $(n=53) ;$ PUBMED $(n=34)$, SciELO $(n=$ 71 ), with a total of 225 publications, of which 09 were duplicates. After selection by exclusion criteria, 183 studies were discarded. After the full reading of the texts, 21 were excluded for not answering the research question.

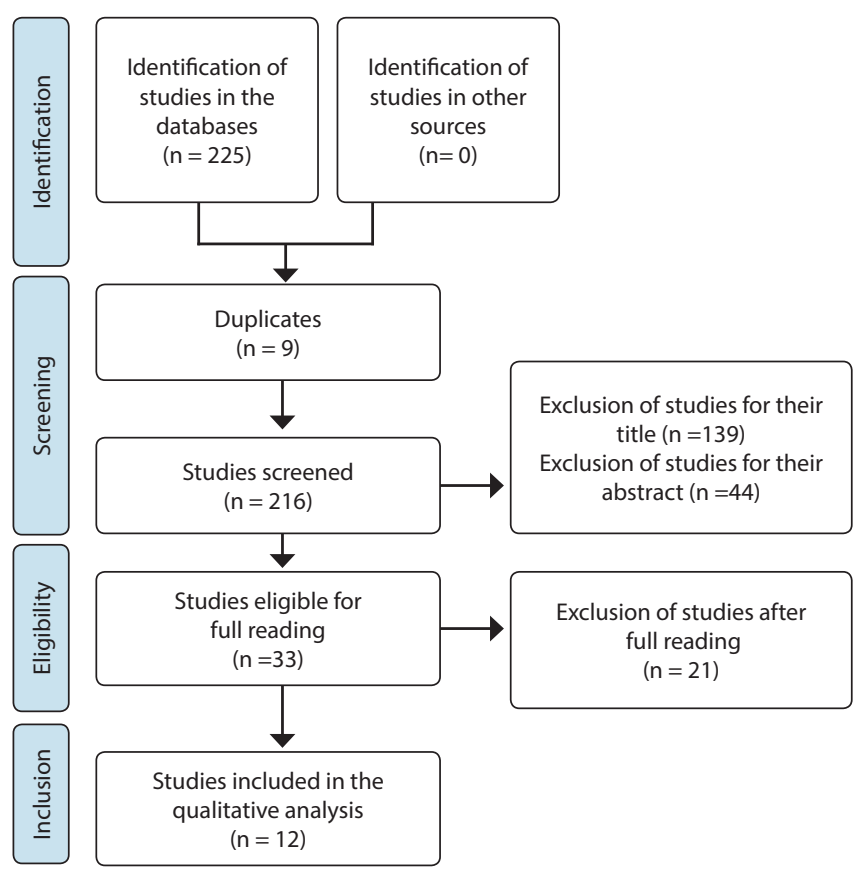

Figure 1 - Flowchart of article selection in databases adapted from Preferred Reporting Items for Systematic Review and Meta-Analyses (PRISMA), 2019 
Thus, the final sample consisted of 12 studies, of which six were found in PUBMED, one in MEDLINE, three in LILACS, one in CINAHL and one in SCIELO. The Preferred Reporting Items for Systematic Reviews and Meta-Analyses (PRISMA) methodology were used to systematize article selection ${ }^{(15)}$. The stages of this process are described in a flowchart (Figure 1).

The twelve articles selected ${ }^{(6,16-26)}$ were published between the years 2004 and 2018. One study was obtained in each year in 2004, 2006, 2008 and 2014, and then the years 2007, 2010, 2012 and 2015 had two studies. The data showed a publication gap in the years 2005, 2009, 2011, 2013, 2016, 2017 and 2018, marked by the absence of studies in these years.

Regarding the place of publication of the studies, eight were international, conducted in the United States of America (USA) and in some European countries. As for national publications, four studies were developed in the states of Pernambuco, Maranhão and Sergipe. Regarding the methodological design, eight studies are descriptive, two are case-control or cohort studies, one is a systematic review and one is a consensus between experts.

The survey developed showed an incipient production of studies on the applicability of management tools (risk score) in the postoperative period of pediatric cardiac surgery by nurses. On the other hand, it was possible to observe a greater production of studies involving the medical staff in the services provided to this population, with the objective of recognizing risk groups for mortality and adopting safety strategies for this population segment. Most of the studies analyzed had a low level of evidence. The synthesis of the studies selected for this review is presented in Chart 2.

Chart 2 - Selected studies on the use of management tools in the care provided to children in the postoperative period of cardiac surgery from 2004 to 2018,2019

\begin{tabular}{|c|c|c|c|}
\hline Title/Database & Journal/Year/Authors & Design/ Objective/ Level of Evidence & Results/Outcome \\
\hline $\begin{array}{l}\text { The RACHS-1 risk categories } \\
\text { reflect mortality and length } \\
\text { of hospital stay in a large } \\
\text { German pediatric cardiac } \\
\text { surgery population } \\
\text { MEDLINE }\end{array}$ & $\begin{array}{l}\text { Eur J Cardio-Thorac Surg } \\
2004 \\
\text { Boethig D, Jenkins KJ, Hecker } \\
\text { H, ThiesWR, Breymann T }{ }^{(16)} \text {. }\end{array}$ & $\begin{array}{l}\text { Descriptive study } \\
\text { Application of the RACHS } 1 \text { score and } \\
\text { analysis of its relation to mortality and } \\
\text { length of hospital stay. } \\
\text { Level: } V\end{array}$ & $\begin{array}{l}\text { Both in-hospital mortality and length } \\
\text { of stay in the ICU were associated with } \\
\text { the RACHS-1 categories. In addition, } \\
\text { mortality in each RACHS-1 category was } \\
\text { equivalent to that reported in larger } \\
\text { institutions in America and Europe. }\end{array}$ \\
\hline $\begin{array}{l}\text { An index for evaluating } \\
\text { results in pediatric cardiac } \\
\text { intensive care. } \\
\text { PUBMED }\end{array}$ & $\begin{array}{l}\text { Cardiol Young } \\
2006 \\
\text { Mattos SS, Neves JR, Costa } \\
\text { MC, Hatem TP, Luna CF (17). }\end{array}$ & $\begin{array}{l}\text { Retrospective cohort study } \\
\text { To determine if in-hospital mortality } \\
\text { after cardiac surgery can be predicted, } \\
\text { in children, using a new clinical and } \\
\text { surgical index. } \\
\text { Level: IV }\end{array}$ & $\begin{array}{l}\text { Accomplishment of an international } \\
\text { work to generate a universally } \\
\text { applicable index to measure mortality } \\
\text { and morbidity in children undergoing } \\
\text { cardiac surgery. }\end{array}$ \\
\hline $\begin{array}{l}\text { Is the RACHS-1 (Risk } \\
\text { adjustment in congenital } \\
\text { heart surgery) a useful tool in } \\
\text { our scenario?? } \\
\text { SCIELO }\end{array}$ & $\begin{array}{l}\text { Rev Bras Cir Cardiovasc } \\
2007 \\
\text { Nina RVAH, Gama MEA, } \\
\text { Santos MAS, Nina VJS, Neto } \\
\text { JAF, Mendes VGG, Lamy ZC, } \\
\text { Brito LMO }{ }^{(18)} \text {. }\end{array}$ & $\begin{array}{l}\text { Retrospective cohort study } \\
\text { To evaluate the applicability of the } \\
\text { RACHS-1 as a predictor of mortality in } \\
\text { the pediatric population of a public } \\
\text { hospital in the Northeast Region of Brazil. } \\
\text { Level: IV }\end{array}$ & $\begin{array}{l}\text { Although the RACHS-1 is easily } \\
\text { applicable, it can not be applied in our } \\
\text { scenario because it does not include } \\
\text { variables that are present in our scenario } \\
\text { and that could interfere in the final } \\
\text { surgical outcome. }\end{array}$ \\
\hline $\begin{array}{l}\text { Accuracy of the Aristotle } \\
\text { Basic Complexity Score for } \\
\text { Classifying the Mortality } \\
\text { and Morbidity Potential of } \\
\text { Congenital Heart Surgery } \\
\text { Operations } \\
\text { PUBMED }\end{array}$ & $\begin{array}{l}\text { Ann Thorac Surg } \\
2007 \\
\text { O'Brien SM, Jacobs JP, Clarke } \\
\text { DR, Maruszewski B, Jacobs } \\
\text { ML, Walters HL }{ }^{(19)} \text {. }\end{array}$ & $\begin{array}{l}\text { Exploratory study through retrospective } \\
\text { data analysis } \\
\text { To assess how well the Aristotle Basic } \\
\text { Complexity Index (ACB score) predicts } \\
\text { the actual morbidity and mortality } \\
\text { potential of } 131 \text { congenital heart surgery } \\
\text { procedures. } \\
\text { Level: } \mathrm{VI}\end{array}$ & $\begin{array}{l}\text { The ABC score generally discriminates } \\
\text { between low-risk and high-risk } \\
\text { procedures, making it a potentially } \\
\text { useful covariate for case-mix adjustment } \\
\text { in congenital heart surgery outcomes } \\
\text { analysis. }\end{array}$ \\
\hline $\begin{array}{l}\text { Post-operative chylothorax in } \\
\text { children: an evidence-based } \\
\text { management algorithm } \\
\text { CINAHL }\end{array}$ & $\begin{array}{l}\text { Journal of Paediatrics \& Child } \\
\text { Health } \\
2008 \\
\text { Panthongviriyakul C, Bines } \\
\text { JE }^{(20)} \text {. }\end{array}$ & $\begin{array}{l}\text { Review study } \\
\text { To develop an evidence-based algorithm } \\
\text { for the management of chylothorax in the } \\
\text { postoperative period of cardiothoracic, } \\
\text { esophageal, mediastinal, diaphragmatic } \\
\text { and pleuropulmonary surgery in children. } \\
\text { Level:VI }\end{array}$ & $\begin{array}{l}\text { Post-operative chylothorax is } \\
\text { associated with significant morbidity } \\
\text { and prolonged hospitalization. An } \\
\text { evidence based algorithm to guide the } \\
\text { therapeutic approach to management of } \\
\text { post-operative chylothorax is proposed. }\end{array}$ \\
\hline $\begin{array}{l}\text { Pediatric cardiac intensive } \\
\text { care unit: current setting and } \\
\text { organization in } 2010 \\
\text { PUBMED }\end{array}$ & $\begin{array}{l}\text { Arch Cardiovasc Dis } \\
2010 \\
\text { Fraisse A, Le Bel S, Mas B, } \\
\text { Macrae D }{ }^{(21)} \text {. }\end{array}$ & $\begin{array}{l}\text { Review study } \\
\text { To evaluate different elements for the } \\
\text { development of a pediatric cardiac } \\
\text { intensive care program based on } \\
\text { clinical experience. } \\
\text { Level:VI }\end{array}$ & $\begin{array}{l}\text { Seriously ill cardiac patients are best } \\
\text { managed in the ICUs designed for them, } \\
\text { which should include a multidisciplinary } \\
\text { team, a specialized nursing team and } \\
\text { perioperative risk stratification. }\end{array}$ \\
\hline $\begin{array}{l}\text { Evaluation of pediatric cardio } \\
\text { surgical model in Croatia by } \\
\text { using the Aristoteles basic } \\
\text { complexity score and the risk } \\
\text { adjustment for congenital } \\
\text { cardiac surgery- } 1 \text { method } \\
\text { PUBMED }\end{array}$ & $\begin{array}{l}\text { Cardiol Young } \\
2010 \\
\text { Dilber D, Malcic I (22). }\end{array}$ & $\begin{array}{l}\text { Review study } \\
\text { To compare the use of the Aristotle } \\
\text { basic complexity score and the risk } \\
\text { adjustment in congenital cardiac } \\
\text { surgery-1 method in centers that } \\
\text { perform pediatric cardiac surgery. } \\
\text { Level:VI }\end{array}$ & $\begin{array}{l}\text { Both, the Aristotle basic complexity } \\
\text { score and the risk adjustment in } \\
\text { congenital cardiac surgery- } 1 \text { method } \\
\text { were predictive of in-hospital mortality } \\
\text { as well as prolonged length of hospital } \\
\text { stay. }\end{array}$ \\
\hline
\end{tabular}




\begin{tabular}{|c|c|c|c|}
\hline Title/Database & Journal/Year/Authors & Design/ Objective/ Level of Evidence & Results/Outcome \\
\hline $\begin{array}{l}\text { Twenty-four hour in- } \\
\text { hospital congenital cardiac } \\
\text { surgical coverage improves } \\
\text { perioperative ECMO support } \\
\text { outcomes } \\
\text { PUBMED }\end{array}$ & $\begin{array}{l}\text { Ann Thorac Surg } \\
2014 \\
\text { Peer SM, Costello JP, Klein } \\
\text { JC, Engle AM, Zurakowski } \\
\text { D, Berger JT, Jonas RA, Nath } \\
\text { DS (23). }\end{array}$ & $\begin{array}{l}\text { Exploratory study through } \\
\text { retrospective data analysis } \\
\text { To evaluate the effect of } 24 \text { hours } \\
\text { coverage on ECMO in congenital heart } \\
\text { surgery children in the perioperative } \\
\text { period. } \\
\text { Level: } \mathrm{VI}\end{array}$ & $\begin{array}{l}\text { The implementation of 24-hour } \\
\text { coverage on ECMO significantly } \\
\text { decreases the mortality rate, pulmonary } \\
\text { complications, and cardiac arrhythmias in } \\
\text { congenital heart surgery children in the } \\
\text { perioperative period. It demonstrates that } \\
\text { congenital heart disease programs would } \\
\text { benefit from this coverage in the care of } \\
\text { this unsafe population. }\end{array}$ \\
\hline $\begin{array}{l}\text { Renal replacement therapy } \\
\text { after cardiac surgery with } \\
\text { extracorporeal circulation } \\
\text { LILACS }\end{array}$ & $\begin{array}{l}\text { Rev Chil Pediatr } \\
2012 \\
\text { Ovalle P, Vogel A, Córdova G, } \\
\text { Cerda J, Cavagnaro SM F(24). }\end{array}$ & $\begin{array}{l}\text { Retrospective, descriptive study. } \\
\text { To determine the incidence of Renal } \\
\text { Replacement Therapy (RRT) in children } \\
\text { undergoing surgical correction of } \\
\text { congenital heart disease and to } \\
\text { identify risk factors for RRT. Level:VI }\end{array}$ & $\begin{array}{l}\text { In this study, the incidence of RRT was } \\
1.6 \% \text {. Severe hypotension and low } \\
\text { cardiac output were significant risk } \\
\text { factors for RRT requirement. Renal } \\
\text { function should be closely evaluated in } \\
\text { patients with surgical events. }\end{array}$ \\
\hline $\begin{array}{l}\text { Heart defects treatment in } \\
\text { Sergipe: propose of resources' } \\
\text { rationalization to improve } \\
\text { care } \\
\text { LILACS }\end{array}$ & $\begin{array}{l}\text { Ver Bras Cir Cardiovasc } \\
2012 \\
\text { Leite DCF, Mendonça JT, } \\
\text { Cipolotti R, Viera EM }{ }^{(25)} \text {. }\end{array}$ & $\begin{array}{l}\text { Descriptive quantitative study } \\
\text { To evaluate the treatment of } \\
\text { congenital heart diseases from 2000- } \\
2009 . \\
\text { Level:VI }\end{array}$ & $\begin{array}{l}\text { The evaluation of RACHS-1 as a predictor } \\
\text { of hospital mortality showed it was } \\
\text { significant. The results indicate that } \\
\text { the centralization and organization } \\
\text { of existing resources are necessary to } \\
\text { improve the performance of surgical } \\
\text { corrections for congenital heart diseases. }\end{array}$ \\
\hline $\begin{array}{l}\text { Principles of shared decision- } \\
\text { making within teams } \\
\text { PUBMED }\end{array}$ & $\begin{array}{l}\text { Cardiol Young } \\
2015 \\
\text { Jacobs JP, Wernovsky G, } \\
\text { Cooper DS, Karl TR }{ }^{(26)} \text {. }\end{array}$ & $\begin{array}{l}\text { Expert consensus. } \\
\text { Analyze the mortality risk model used } \\
\text { by the Society Thoracic Surgeons (STS) } \\
\text { to publicly report the outcomes of } \\
\text { congenital heart surgery. } \\
\text { Level:VII }\end{array}$ & $\begin{array}{l}\text { In an environment of strong disagreement, } \\
\text { the use of the mortality risk model (STS) } \\
\text { serves to estimate the number of expected } \\
\text { deaths among patients, enabling true } \\
\text { teamwork and shared decision-making, } \\
\text { which are fundamental to obtain excellent } \\
\text { health outcomes. }\end{array}$ \\
\hline $\begin{array}{l}\text { Stratification of complexity } \\
\text { in congenital heart surgery: } \\
\text { comparative study of the Risk } \\
\text { Adjustment for Congenital } \\
\text { Heart Surgery (RACHS-1) } \\
\text { method, Aristotle basic score } \\
\text { and Society of Thoracic } \\
\text { Surgeons-European Association } \\
\text { for Cardio-Thoracic Surgery } \\
\text { (STS-EACTS) mortality score } \\
\text { LILACS }\end{array}$ & $\begin{array}{l}\text { Rev Bras Cir Cardiovasc } \\
2015 \\
\text { Cavalcanti PEF, Sá MPBO, } \\
\text { Santos CA, Esmeraldo IM, } \\
\text { Chaves ML, Lins RFA, Lima } \\
\text { RC }^{(6)} \text {. }\end{array}$ & $\begin{array}{l}\text { Descriptive quantitative study } \\
\text { To determine whether stratification } \\
\text { of complexity models in congenital } \\
\text { heart surgery (RACHS-1, Aristotle basic } \\
\text { score and STS-EACTS mortality score) } \\
\text { fit to our center and determine the } \\
\text { best method of discriminating hospital } \\
\text { mortality. } \\
\text { Level: VI }\end{array}$ & $\begin{array}{l}\text { The three models of stratification of } \\
\text { complexity currently available in the } \\
\text { literature are useful even with different } \\
\text { mortality rates between the categories } \\
\text { proposed. With similar discriminatory } \\
\text { capacity for hospital mortality outcome, } \\
\text { it was not possible to determine the } \\
\text { superiority of one method over another } \\
\text { in the sample. }\end{array}$ \\
\hline
\end{tabular}

\section{DISCUSSION}

Aiming to better divide the findings and discuss them through convergent subjects, they were categorized into two units of analysis, namely: emerging strategies in child health care in the postoperative period of cardiac surgery; and applicability of prognostic indexes as support in the management of care provided to children in the postoperative period of cardiac surgery.

\section{1 - Emerging strategies in child health care in the postop- erative period of cardiac surgery}

The postoperative period of CHD requires understanding and evaluation of several factors, which include the anatomy and physiology of heart disease, the patient's preoperative condition, the surgical technique use and the clinical recovery. These variables require close and strict attention from the health team, especially from nurses, due to their potential to produce multisystem effects ${ }^{(27)}$.

In this perspective, in January, 2015, the Society of Thoracic Surgeons (STS) began to publicly report outcomes of congenital cardiac surgery using the Society of Thoracic Surgeons Congenital Heart Surgery Database (STS-CHSD) Model. This mortality risk model facilitates the description adjusted by procedure. Therefore, it is an important tool for the evaluation of complexity, enabling comparison between hospitals based on the type of operations they perform. In addition, it helps providing excellent results in healthcare ${ }^{(26)}$.

In this context, it is necessary to have a trained and qualified multidisciplinary team ${ }^{(28)}$ as well as tools that provide the safety required in this context. Cardiovascular surgery is an intervention that involves highly complex procedures, such as Extracorporeal Circulation (ECC) ${ }^{(29)}$, which more frequently require the adoption of strategies to improve the assistance provided.

A study ${ }^{(23)}$ developed in the USA reports the use of Extracorporeal Membrane Oxygenation (ECMO) as support in the management of children with complex CHD. Since the 1990s, this method has been used to rescue patients requiring cardiopulmonary resuscitation after cardiac surgery. However, the study reports that the adoption of this strategy is subject to significant variability of factors intrinsically related to achieve good results, such as a specialized medical team, 24-hour in-hospital congenital cardiac surgical coverage (24-CCSC) and a quick start in the implementation of the strategy.

In general, the presence of a child cardiac surgeon contributes to an improved survival of these patients, as it allows a safe cannulation during cardiopulmonary resuscitation and prevents risk 
situations in advance. In addition, the cardiac surgeon manages the team and gets immediately involved with the care and the management of complications of $\mathrm{ECMO}^{(23)}$.

Thus, the implementation of 24-CCSC significantly decreased mortality rate, pulmonary complications and cardiac arrhythmias in children supported with ECMO after cardiac surgery. These results demonstrated that 24-CCSC improved the survival of patients supported with ECMO in the perioperative period ${ }^{(23)}$.

Among the complications associated with the postoperative period of CHD, the most prevalent is Acute Renal Insufficiency (ARI). This does not depend on the technological advances of ECC, as well as the procedures in the intra and postoperative period, corresponds to a high rate of postoperative morbidity and mortality ${ }^{(30)}$, with reported incidence between 17 and $72 \%{ }^{(24)}$.

The ECC ${ }^{(25)}$ regulates several factors involved in the deterioration of kidney function, precisely because it is a technology that does not maintain principles of human physiology, contributing to physiological changes with important repercussions, such as pulmonary, neurological, cardiac, infectious, acid-base, hematological, glycemic and renal alterations in the postoperative period. Therefore, in the postoperative period, the need for Renal Replacement Therapy (RRT) becomes constant, varying between 2.9 and $17 \%$ according to authors ${ }^{(31-33)}$.

A research ${ }^{(24)}$ carried out in Chile, reported that the incidence of RRT in the postoperative period of cardiac corrections with ECC was lower than that reported in other studies ${ }^{(31-32,34)}$. However, it highlighted the implementation of ultrafiltration at the end of ECC in almost all patients, which facilitated strict volume control in the postoperative period and reduced the need for RRT due to hypervolemia. This strategy was not mentioned in other studies ${ }^{(24)}$. In addition, it emphasized that the use of this strategy may be related to a mortality rate corresponding to $40 \%$, showing results similar to other studies which found values between $20-80 \%^{(31-}$ 32,34-37). Likewise, no patient died with ARI as the direct cause.

Another tool mentioned was the creation of an algorithm ${ }^{(20)}$ to control complications and mortality caused by chylothorax, a common manifestation associated with the increasing complexity of cardiothoracic surgery.

Chylothorax is characterized by loss of lymphocytes, lipids, proteins, glucose, and electrolytes ${ }^{(20)}$ Thus, nutritional support and strategies to limit the volume and duration of fluid loss are implemented to reduce complications such as sepsis and poor wound healing, reducing morbidity and mortality.

In the last 15 years, the incidence of chylothorax in cardiac surgeries has increased from 0.9 to $1.5 \%$ to $6.6 \%{ }^{(38-39)}$, which certainly reflects the complexity of some surgical corrections, such as Fontan, tetralogy of Fallot and heart transplant.

\section{2-Applicability of prognostic indexes as support in the management of care provided to children in the postop- erative period of cardiac surgery.}

The expectation of fast access and quality health care, especially in Intensive Care Units (ICU), is increasing in our country ${ }^{(40)}$. This requires pediatric nursing professionals to use tools to enable the provision of quality care to children in the postoperative period of cardiac surgery ${ }^{(41)}$.
The risk adjustment in congenital heart surgery is difficult to estimate due to wide variations in anatomy and physiology. In addition, other limiting factors are the differences in the underlying diseases and the nature of the necessary surgical procedure for correction ${ }^{(22)}$.

In the 1980s, prognostic indexes and scores began to spread in the ICU. These tools attribute numerical values to the clinical and laboratory conditions of patients and then, using a logarithmic equation, returns a numerical scale that can classify disease severity, compare estimated mortality in percentage with observed mortality, and allow adjustments between services by comparing results ${ }^{(42-43)}$.

Risk stratification in pediatric and neonatal ICUs represents a great challenge, and some risk models have been proposed: Risk Adjustment for Congenital Heart Surgery 1 (RACHS 1) ${ }^{(5)}$ and the Aristotle Basic Score (ABC) Complexity ${ }^{(21)}$.

A study ${ }^{(21)}$ carried out in Croatia compared the use of the $A B C$ score and the RACHS-1 among the centers that provided surgical correction and proved the effectiveness of the instruments as predictors of in-hospital mortality and potential complications. However, the difference between institutions is highlighted due to the anatomical variation of the disease and the nature of the surgical procedure necessary for its correction.

Another study ${ }^{(16)}$ concluded that the RACHS 1 score, when applied to a European pediatric population, was able to classify patients into groups, but not individually. This study also analyzed the relationship of the score and mortality rate and length of hospital stay, despite of the great variability among the group of patients with CHD.

The RACHS 1 classification in another study ${ }^{(44)}$ also presented a good control group, but low individual predictive capacity in relation to the length of hospital stay and mortality in a given population. The $A B C$ score obtained a higher predictive value in more complex surgical corrections.

Among the factors that affect the analysis of the quality of care provided to patients undergoing surgical correction of CHD, the following stand out: the underlying disease, the plurality of diagnosis, age and nutritional status. All of these factors complicate the use of existing scores as tools for a careful analysis of the patient's clinical conditions ${ }^{(19)}$.

Another study ${ }^{(17)}$ investigated if in-hospital mortality after CHD surgical correction can be predicted using a clinical and surgical index. It found that surgeries undertaken in the neonatal period, even when associated with some risk factors such as low weight, associated clinical risk factors, higher complexity heart disease and a ECC time greater than 90 minutes, were all significantly associated with mortality. The study also mentioned that the evaluation of more complex surgeries benefited from the use of the $A B C$ score, as it focused specifically on complex surgeries, which made it a potentially useful covariate in these cases.

The same difficulty for the prediction of mortality was also observed in a research that compared the Pediatric Risk of Mortality (PRISM) and the Pediatric Index of Mortality (PIM) scores in a general ICU. This study investigated the relation between observed mortality and survival with mortality and survival estimated by scores and concluded that the presence of variables that were not measured by these scores made it difficult to classify the severity level of different patients in different units, which affected its discriminatory capacity ${ }^{(45)}$. 
In this regard, it is worth highlighting some difficulties in the evaluation of the death risk after surgical correction of CHD in developing countries, such as advanced malnutrition, severe cyanosis, pulmonary hypertension, prematurity, among others, which are associated with the late diagnosis or referral of these patients ${ }^{(2)}$.

These situations indicate the need to have an international group work to examine different surgical realities and generate a universally applicable index, which would give a better outline of the morbidity and mortality in children undergoing cardiac surgery worldwide ${ }^{(2)}$.

A concurrent validation of the nursing scores Nine Equivalents of Nursing Use Manpower (NEMS) and Therapeutic Intervention Scoring System (TISS 28) ${ }^{(18)}$ concluded that both scores had good correlation, good discriminatory capacity for mortality, and good association with the PRISM. Nevertheless, it pointed out that the more therapeutic interventions pediatric patients must undergo, the higher the scores and consequently their severity.

Several scores have been developed and disseminated with the purpose of correlating mortality with and disease, among which RACHS 1 is the most used ${ }^{(25)}$.

Another survey ${ }^{(6)}$ aimed to verify if the RACHS 1, ABC model and the Mortality Scale are useful to determine different mortality rates between the proposed categories and to find which method would be most suitable for this institution. The analysis of the three models of stratification showed different mortality rates between the proposed categories and, due to the similar discriminatory capacity for hospital mortality, it was not possible to determine the superiority of method over another.

\section{Study limitations}

In this study it was possible to identify studies developed in Brazil assessing the applicability of three models of stratification of complexity: RACHS-1 Score, Aristotle Basic Score and Mortality Score (STS-EACTS). The studies found different results regarding the discriminatory capacity of the scores for the outcome hospital mortality among children with heart disease. One of the studies found good discriminatory capacity in the application of the models of stratification, while other studies pointed out difficulties such as the need to centralize and organize the existing resources to improve the performance of surgical corrections. In addition, the RACHS-1 Score did not demonstrate a good discriminatory capacity as it did not include some variables that are present in the Brazilian reality.

Another limitation concerns the of available data on the prevalence of complications among children after cardiac surgery, which prevents the understanding of this aspect and hinders the progress in the quality of outcomes. In addition, there is an incipient scientific production by nursing professionals on heart disease as one of the main congenital malformations, and on its clinical approach and care management, especially in the postoperative period of cardiac surgery.

\section{Contributions to the nursing area, health or public policy}

The applicability of RACHS-1 and Aristotle Basic Score stands out in Brazil. These models aim to describe the surgical mortality adjusted to the surgical intervention to support decision making, seeking to achieve different results, as congenital heart disease represents a serious public health problem in Brazil and around the world. This problem is the first cause of death among all congenital malformations, and most of these defects are corrected by surgeries that are considered highly complex and long procedures.

Thus, this study contributes by increasing the knowledge about the use of management tools to support care, helping in the early detection of complications resulting from the surgeries and enabling the team, especially nursing professionals, to recognize clinical and hemodynamic alterations that require immediate intervention, aiming to reduce complications and mortality.

\section{FINAL CONSIDERATIONS}

According to scientific evidence, the use of pediatric scores and other emerging strategies to control mortality in the postoperative period of CHD was effective for the development and/ or efficiency of the treatments. Scientific evidence pointed out that among the most used scores in pediatric care, RACHS-1 had the highest predictive capacity for mortality in this population.

It can be said that the knowledge and the use of these tools have a great clinical implication for nursing, as they enable a different management practice and present excellent discriminatory and predictive capacity for assessing the severity of the disease and measuring the real needs, so that individualized care can be provided.

A knowledge gap was the necessity of comparing performance between pediatric cardiology services with demonstration of results through a large database shared between centers specialized in congenital heart disease. With this, it would be possible to measure and compare the results found between centers and with international references, aiming to recognize complications in a timely manner, select appropriate treatment, reduce mortality rates, and encourage the development of new studies.

\section{REFERENCES}

1. Aragão JA, Mendonça MP, Silva NS, Moreira NA, Sant'Anna MEC, Reis FP. O perfil epidemiológico dos pacientes com cardiopatias congênitas submetidos à cirurgia no Hospital do Coração. Rev Bras Ciênc Saúde. 2013;17(3):263-8. https://doi.org/10.4034/RBCS.2013.17.03.08

2. Caneo LF, Jatene MB, Yatsuda N, Gomes WJ. Uma reflexão sobre o desempenho da cirurgia cardíaca pediátrica no Estado de São Paulo. Rev Bras Cir Cardiovasc. 2012;27(3):457-62. https://doi.org/10.5935/1678-9741.20120076

3. Bastos LF, Araújo TM, Frota NM, Caetano JA. Perfil Clinico e Epidemiológico de Crianças com Cardiopatias congênitas Submetidas à Cirurgia Cardíaca. Rev Enferm UFPE 2013;7(8):5298-304. https://doi.org/10.5205/reuol.3452-28790-4-ED.0708201330 
4. Hoscheidt LM, Moraes MAPM, Witkowski MC. [Nursing care complexity in children undergoing cardiac surgery]. Rev Pesqui Saúde. 2014;15(1):203-7. Available from: http://www.periodicoseletronicos.ufma.br/index.php/revistahuufma/article/view/3049 Portuguese.

5. Clavería C, Cerda J, Becker, Schiele C, Barreno B, Urcelay G, et al. Mortalidad operatoria y estratificación de riesgo en pacientes pediátricos operados de cardiopatía congénita: experiencia de 10 años. Rev Chil Cardiol. 2014;33(1):11-9. https://doi.org/10.4067/ S0718-85602014000100001

6. Cavalcanti PEF, Sá MPBO, Santos CA, Esmeraldo IM, Chaves ML, Lins RFA, et al. Stratification of complexity in congenital heart surgery: comparative study of the Risk Adjustment for Congenital Heart Surgery (RACHS-1) method, Aristotle basic score and Society of Thoracic Surgeons-European Association for Cardio- Thoracic Surgery (STS-EACTS) mortality score. Rev Bras Cir Cardiovasc. 2015;30(2):148-58. https://doi.org/10.5935/1678-9741.20150001

7. Cavalcante OS, Rossaneis MA, Haddad MCL, Gabriel CS. Indicadores de qualidade utilizados no gerenciamento da assistência de enfermagem hospitalar. Rev Enferm UERJ. 2015;23(6):787-93. https://doi.org/10.12957/reuerj.2015.7052

8. Santos TBS, Moreira ALA, Suzart NA, Pinto ICM. Gestão hospitalar no Sistema Único de Saúde: problemáticas de estudos em política, planejamento e gestão em saúde. Rev Ciênc Saúde Coletiva. 2020;25(9):3597-609. https://doi.org/10.1590/1413-81232020259.33962018

9. Goulart LL, Carrara FSA, Zanei SSV, Whitaker IY. Carga de trabalho de enfermagem relacionada ao índice de massa corporal de pacientes críticos. Acta Paul Enferm. 2017;30(1):31-38. https://doi.org/10.1590/1982-0194201700006

10. Mororó DDS, Menezes RMP, Queiroz AAR, Silva CJA, Pereira WC. Nurse as an integrator in healthcare management of children with chronic condition. Rev Bras Enferm. 2020;73(3):e20180453. https://doi.org/10.1590/0034-7167-2018-0453

11. Cecilio HPM, Oliveira DC. Modelos de revisão integrativa: discussão na pesquisa em Enfermagem. CIAIQ 2017 Atas Investigação Qualitativa em Saúde[Internet]. 2017 [cited 2020 Dec 09];(2)764-72. Avaible from: https://proceedings.ciaiq.org/index.php/ciaiq2017/article/view/1272

12. Sousa MM, Marques JM, Nobre MRC, Firmino CF, Frade F, Valentim OS, et al. Modelos de formulação da questão de investigação na prática baseada na evidência. Rev Investig Enferm[Internet]. 2018[cited 2020 Dec 09];31-39. Available from: http://hdl.handle. net/20.500.12253/1287

13. Pinto Jr VCP, Fraga MNO, Freitas SM. Análise das portarias que regulamentam a Política Nacional de Atenção Cardiovascular de Alta Complexidade. Rev Bras Cir Cardiovasc. 2012;27(3):463-8. https://doi.org/ 10.5935/1678-9741.20120077

14. Melnyk BM, Fineoutoverholt E. Evidence-based practice in nursing \& healthcare: a guide to best practice. 4 ed. Philadelphia: Wolters Kluwer Health; 2019. 1157p.

15. Moher D, Liberati A, Tetzlaff J, Altman DG, Altman D, Antes G, et al. Preferred reporting items for systematic reviews and meta-analyses: the PRISMA statement. PLoS Med. 2009;6(7):1-6. https://doi.org/10.1371/journal.pmed.1000097

16. Boething D, Jenkins KJ, Hecker $H$, Thies WR, Breymann T. The RACHS-1 risk categories reflect mortality and length of hospital stay in a large German pediatric cardiac surgery population. Eur J Cardiothorac Surg. 2004;26(1):12-7. https://doi.org/10.1016/j.ejcts.2004.03.039

17. Mattos SS, Neves JR, Costa MC, Hatem TP, Luna CF. An index for evaluating results in paediatric cardiac intensive care. Cardiol Young. 2006;16(4):369-77. https://doi.org/10.1017/S1047951106000357

18. Nina RVAH, Gama MEA, Santos AMS, Nina VJS, Figueiredo Neto JAF, Mendes VGG, et al. O escore de risco ajustado para cirurgia em cardiopatias congênitas (RACHS-1) pode ser aplicado em nosso meio? Rev Bras Cir Cardiovasc. 2007;22(4):425-31. https://doi.org/10.1590/ S0102-76382007000400008

19. O'Brien SM, Jacobs JP, Clarke DR, Maruszewski B, Jacobs ML, Walters HL, et al. Accuracy of the aristotle basic complexity score for classifying the mortality and morbidity potential of congenital heart surgery operations. Ann Thorac Surg. 2007;84(6):2027-37. https://doi. org/10.1016/j.athoracsur.2007.06.031

20. Panthongviriyakul C, Bines JE. Post-operative chylothorax in children: an evidence-based management algorithm. J Paediatr Child Health. 2008;44(12):716-21. https://doi.org/10.1111/j.1440-1754.2008.01412.x

21. Fraise AL, Le Bel S, Mas B, Macrae D. Pediatric cardiac intensive care unit: current setting and organization in 2010. Arch Cardiovasc Dis. 2010;103(10):546-51. https://doi.org/10.1016/j.acvd.2010.05.004

22. Dilber D, Malcic l. Evalution of paediatric cardiosurgical mode in Croatia by using the Aristotele basic complexity escore and the risk adjustment for congenital cardiac surgery- 1 method. Cardiol Young. 2010;20(4):433-40. https://doi.org/10.1017/S1047951110000193

23. Peer SM, Costello JP, Klein JC, Engle AM, Zurakowski D, Berger JT. Twenty-four hour in-hospital congenital cardiac surgical coverage improves perioperative ECMO support outcomes. Ann Thorac Surg. 2014;98(6):2152-7. https://doi.org/10.1016/j.athoracsur.2014.07.042

24. Ovalle P, Vogel A, Córdova G, Cerda J, Cavagnaro F. Reemplazo renal en el post-operatorio de niños sometidos a cirugía cardíaca con circulación extracorpórea. Rev Chil Pediatr. 2012;83(1):24-32. https://doi.org/10.4067/S0370-41062012000100003

25. Leite DCF, Mendonça JT, Cipolotti R, Melo EV. Tratamento das cardiopatias congênitas em Sergipe: proposta de racionalização dos recursos para melhorar a assistência. Rev Bras Cir Cardiovasc. 2014;27(2):224-30. https://doi.org/10.5935/1678-9741.20120038

26. Jacobs JP, Wernovsky G, Cooper DS, Karl TR. Principles of shared decision-making within teams. Cardiol Young. 2015;25(8):1631-6. https:// doi.org/10.1017/S1047951115000311

27. Ascenzi JA, Kane PL. Update on complications of pediatric cardiac surgery. Crit Care Nurs Clin North Am. 2007;19(4):361-9. https://doi. org/10.1016/j.ccell.2007.08.003 
28. Caneo LF, Jatene MB, Riso AA, Tanamati C, Penha J, Moreira LF, et al. Avaliação do tratamento cirúrgico da cardiopatia congênita em pacientes com idade superior a 16 anos. Arq Bras Cardiol. 2012;98(5):390-7. https://doi.org/10.1590/S0066-782X2012005000030

29. Oliveira JMA, Silva AMF, Cardoso SB, Lima FF, Zierer MS, Carvalho ML. Complicações no pós-operatório de cirurgia cardiovascular com circulação extracorpórea. Rev Interdisciplin. 2015;8(1):9-15.

30. Moura EB, Bernardes Neto SCG, Amorim FF, Viscardi RC. Correlação do EuroSCORE com o surgimento de lesão renal aguda pós-operatória. Rev Bras Ter Intensiva. 2013;25(3):233-8. https://doi.org/10.5935/0103-507X.20130040

31. Cabas L, Montes RF, Kling JC, Rincón JD, Rincón I, Giraldo JC, et al. Disfunción renal en postoperatorio de cirugía cardíaca pediátrica con circulación extracorpórea. Rev Colomb Anestesiol [Internet]. 2005[cited 2020 Dec 09];33(2):85-91. Available from: https://www.researchgate. net/publication/262446529_Disfuncion_renal_en_postoperatorio_de_cirugia_cardiaca_pediatrica_con_circulacion_extracorporea

32. Kist-van Holthe tot Echten JE, Goedvolk CA, Doornaar MB, van der Vorst MM, Bosman-Vermeeren JM, Brand R, et al. Acute renal insufficiency and renal replacement therapy after pediatric cardiopulmonary bypass surgery. Pediatr Cardiol. 2001;22(4):321-6. https://doi.org/10.1007/ s002460010238

33. Baskin E, Saygili A, Harmanci K, Agras PI, Ozdemir FN, Mercan S, et al. Acute renal failure and mortality after open-heart surgery in infants. Renal Fail. 2005;27(5):557-60. https://doi.org/10.1080/08860220500199035

34. Boigner H, Brannath W, Hermon M, Stoll E, Burda G, Trittenwein G, et al. Predictors of mortality at initiation of peritoneal dialysis in children after cardiac surgery. Ann Thorac Surg. 2004;77(1):61-5. https://doi.org/10.1016/S0003-4975(03)01490-5

35. Chan KL, Ip P, Chiu CS, Cheung YF. Peritoneal dialysis after surgery for congenital heart disease in infants and young children. Ann Thorac Surg. 2003;76(5):1443-9. https://doi.org/10.1016/S0003-4975(03)01026-9

36. Pedersen KR, Hjortdal VE, Christensen S, Pedersen J, Hjortholm K, Larsen SH, et al. Clinical outcome in children with acute renal failure treated with peritoneal dialysis after surgery for congenital heart disease. Kidney Int Suppl. 2008;(108):S81-6. https://doi.org/10.1038/ sj.ki.5002607

37. Romao JE Jr, Fuzissima MG, Vidonho AF Jr, Noronha IL, Quintaes PS, Abensur H, et al. Outcome of acute renal failure associated with cardiac surgery in infants. Arq Bras Cardiol. 2000;75(4):318-21. https://doi.org/10.1590/S0066-782X2000001000006

38. Allen EM, van Heeckeren DW, Spector ML, Blumer JL. Management of nutritional and infectious complications of postoperative chylothorax in children. J Paediatr Surg. 1991;26(10):1169-74. https://doi.org/10.1016/0022-3468(91)90325-N

39. Chan EH, Russell JL, Williams WG, Van Arsdell GS, Coles JG, McCrindle BW. Postoperative chylothorax after cardiothoracic surgery in children. Ann Thorac Surg. 2005;80(5):1864-70. https://doi.org/10.1016/j.athoracsur.2005.04.048

40. Canabarro ST, Velozo KDS, Eidt OR, Piva JP, Garcia PCR. Validação Concorrente de Escores de Enfermagem (NEMS e TISS-28) em terapia intensiva pediátrica Concurrent Validation of Nursing Scores (NEMS and TISS-28) in pediatric intensive care. Acta Paul. Enferm. 2013;26(2):123-9. https://doi.org/10.1590/S0103-21002013000200004

41. Camelo SHH, Soares MI, Chaves LDP, Rocha FLRR, Silva VLS. Enfermeiros gerentes de um hospital de ensino: formação profissional, responsabilidades e desafios. Rev Enferm UERJ. 2016;24(3):e11637. https://doi.org/10.12957/reuerj.2016.11637

42. Silva LMS, Martins LF, Santos MCFC, Oliveira RM. Índices prognósticos na prática clínica de enfermagem em terapia intensiva: revisão integrativa. Rev Eletrôn Enferm. 2014;16(1):179-90. http://dx.doi.org/10.5216/ree.v16i1.22830

43. Oliveira VCR, Nogueira LS, Andolhe R, Padilha KG, Sousa RMC. Evolução clínica de adultos, idosos e muito idosos internados em Unidade de Terapia Intensiva. Rev Latino-Am Enferm. 2011;19(6):1344-51. https://doi.org/10.1590/S0104-11692011000600010

44. Putman LM, Takkenberg JJ, Bogers AJ. Risk stratification for adult congenital heart surgery. Eur J Cardiothorac Surg. 2011;39(4):490-4. https://doi.org/10.1016/j.ejcts.2010.07.032

45. Martha VF, Garcia PCR, Piva JP, Einloft PR, Bruno F, Rampon V. Comparação entre dois escores de prognóstico (PRISM e PIM) em unidade de terapia intensiva pediátrica. J Pediatr. (Rio J.). 2005;81(3):259-64. https://doi.org/10.2223/1348 